\title{
Selvmord og \\ selvmordsforsøk blant unge innvandrere
}

\author{
Ved Berit Grøholt
}

I internasjonal forskning om selvmordsatferd blant unge er etnisitet inkludert som en selvfølge, spesielt $i$ USA (CDC staff 1999). Dette bør bli vanlig også i Norge, men i dag har vi liten konkret kunnskap om selvmordsatferd i gruppen av ungdom med utenlandsk opprinnelse, eller med foreldre vokst opp i andre land. De norske studiene av selumordsatferd som har vaert publisert har i liten grad hatt dette som fokus, blant annet fordi gruppene som har vaert undersøkt, er relativt små.

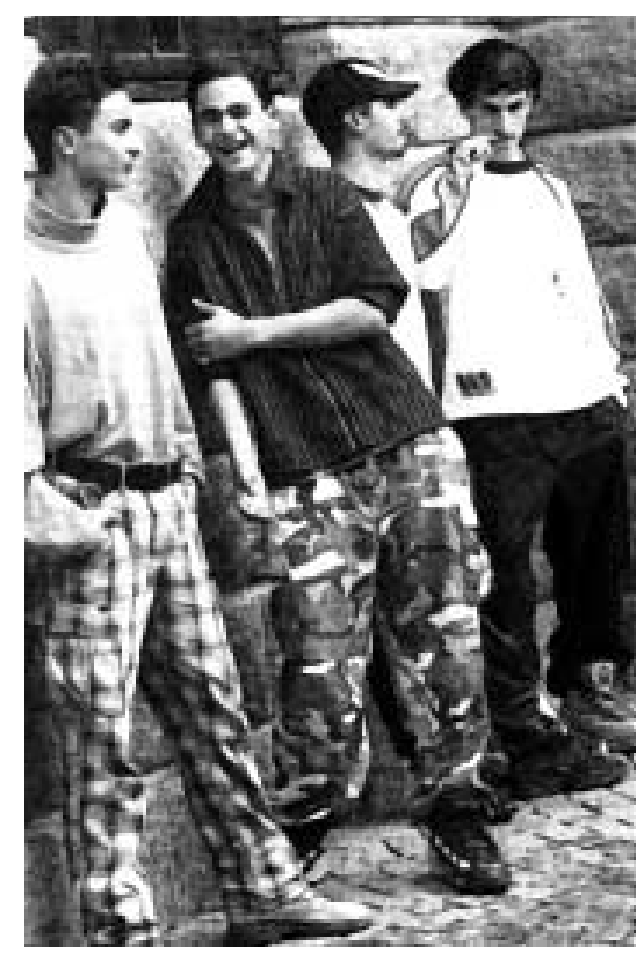

$M$ an kunne tenke seg at unge med innvandrerbakgrunn har hatt og har større problemer enn barn med foreldre født og vokst opp i N orge. Dermed kunne hypotesen være at de er mer utsatt for å ty til selvmordsatferd enn andre. På den annen side er spesielt muslimene mer religiøse enn gjennomsnittsprotestanten i N orge, og sterk tilknytning til religion kunne virke beskyttende. 0 gså sterkt familiesamhold som karakteriserer mange kulturer mer enn den norske, kunne virke beskyttende.

I denne artikkelen vil vi trekke fram funn som for en stor del ikke har vært publisert tidligere. Dette er funn fra to studier av unge under 20 år i N orge. En av studiene omfatter 129 selvmord i 1990-1992 (G røholt et al. 1997), og en annen omfatter 92 selvmordsfors $\varnothing \mathrm{k} i$ samme aldersgruppe, der de unge ble innlagt på sykehus i 0 slo eller A kershus ( $G$ røholt et al. 2000). I begge studiene har vi sammenliknet med store representative utval $g$ av vanlig ungdom med samme alders- og kjønnsfordeling, slik at vi kan se hvordan unge med selvmordsatferd avviker fra gjennomsnittsbefolkningen.

\section{Definisjoner}

I studiene har vi notert foreldrenes opprinnelsesland i følgen de kategorier: norsk, vestlig (fra Europa, A merika eller A ustralia) eller ikke-vestlig ( $A$ sia og A frika). $\mathrm{N}$ år vi bruker betegnel sen unge med innvandrerbakgrunn, inkluderer vi noe upresist de som har foreldre fra A frika eller A sia. Det betyr at vi ikke har skilt mellom flyktninger og innvandrere, og vi har ikke lagt vekt på om de unge er født i N orge eller hvor lenge de har bodd her. Vi har også registrert hvor mange som var adoptert fra utlandet.

\section{Undersøkelse om selvmord}

0 mtrent like mange hadde norske foreldre blant de som døde av selvmord ( $97 \%$ ) og blant gjennomsnittsungdommen $(93 \%)$. Av disse var henholdsvis $1,6 \%$ og 1,8 \% adoptert fra utlandet. Ingen av de som døde, hadde første- eller annengenerasjonsforeldre fra A sia eller A frika, mot $1,7 \%$ av gjennomsnittsungdom. Blant de som døde av selvmord hadde $1,6 \%$ en eller to foreldre fra vestlige land utenfor $\mathrm{N}$ orge, mot 5,3\% av gjennomsnittsunge.

Vi har altså ingen holdepunkter for at barn av foreldre med utenlandsk opprinnelse er mer utsatt for selvmord enn andre. $\mathrm{V}$ åre funn trekker snarere i motsatt retning, men tallene er små og forskjellen for liten til at det har noen beviskraft (de er ikke statistisk signifikante: Fisher's exact test $>0.1$ ).

\section{Undersøkelse av selvmordsforsøk}

U ndersøkelsen blant unge innlagt etter selvmordsforsøk ble foretatt to år senere (1992-1994) i O slo og A kershus. Blant gjennomsnittsungdommen i dette området hadde $90 \%$ forel dre som hadde vokst opp i N orge, mens $79 \%$ av de unge som forsøkte selvmord hadde slike foreldre. Foreldrene kom fra andre vestlige land for $4,4 \%$ av vanlig ungdom og 6,6 \% av de unge selvmordsforsøkerne. Hele $14,3 \%$ av selvmordsforsøkerne hadde foreldre fra A sia eller A frika, mot 5,5\% av gjennomsnittsungdommen. Forskjellene nevnt over var såpass store at de neppe skyldtes tilfeldigheter $(p=0.02)$.

U nge som hadde bodd mindre enn 5 år i N orge, var overrepresentert blant de som forsøkte selvmord. Her utgjorde de $9 \%$ mot $1 \%$ i gjennomsnittsbefolkningen. $(p<0.001)$. M en det spilte ingen rolle om de kom fra Europa, USA, A sia eller A frika.

\section{Flere forhold virker sammen}

I statistiske analyser har vi mulighet for å se på hvordan ulike faktorer virker sammen. Vi fant at barn i familier med lav sosial status, i dette tilfellet ofte med arbeidsløse eller trygdede foreldre, hadde øt risiko for å forsøke selvmord. N år vi så på innvandrerbakgrunn og sosial klasse i sammenheng, så vi at det var lav sosial status som forklarte den økte risikoen for selvmordsforsøk, og at det da ikke spilte noen rolle hvor foreldrene kom fra (Funnene ble analysert ved hjelp av logistisk regresjon. For detaljer se $\mathrm{G}$ røholt et al. 2000).

\section{Ingen forskjell?}

Vi fant altså ingen statistisk signifikant forskjell mellom unge med innvandrerbakgrunn og andre unge når det gjelder risiko for selvmord eller selvmordfforsøk. A llikevel var det interessante forskjeller mellom de unge, knyttet til deres kulturelle og religiøse bakgrunn. Beskrivelsen av forskjellene som følger, baserer seg på inntrykk mer enn på vitenskapelige vurderinger. Tydeligst var forskjellene når vi så på hvilke grunner de unge oppga for sin fortvilelse. N oen av innvandrerjentene var opptatt av at de ikke hadde vært gode døtre, og ikke hadde vært hjelpsomme nok eller gjort så gode gjerninger for sine forel dre som de skyldte dem. Den typen betraktninger forekom ikke blant de unge 


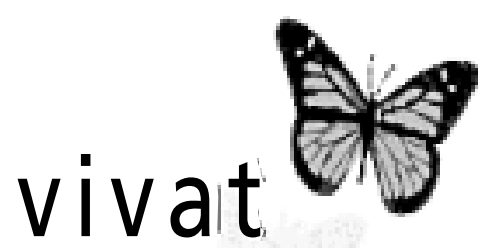

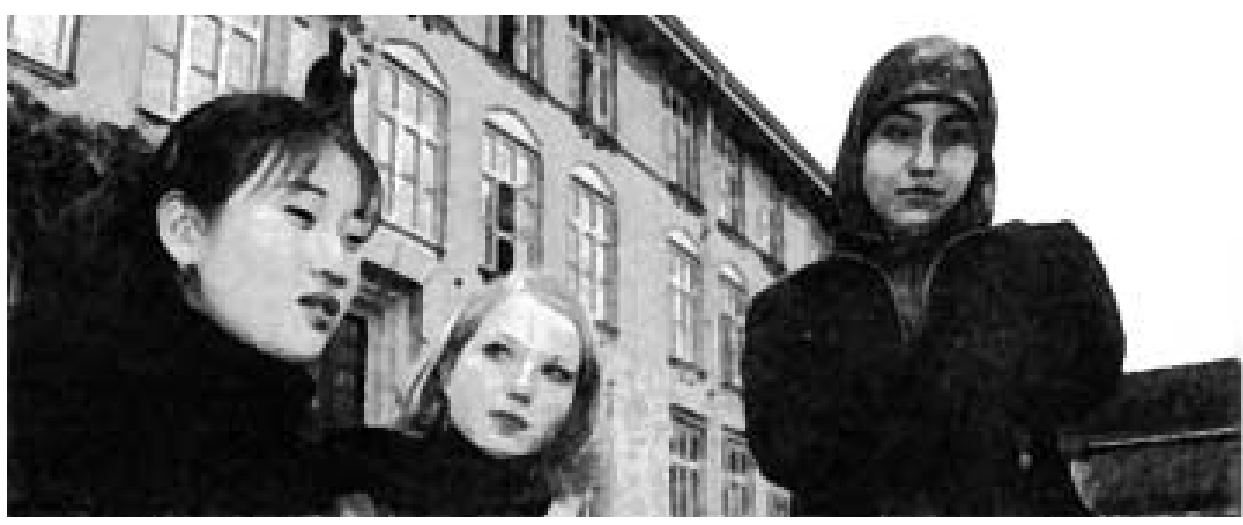

norske. De kunne nok snakke om at de var lei seg fordi de hadde skuffet foreldrene med dårlige handlinger, men de beskrev aldri at de ikke hadde gjort nok for dem i positiv forstand.

Seksuelle forhold var kompliserte på en annen måte blant de unge med foreldre med utenlandsk opprinnelse. I flere tilfeller bunnet deres fortvilelse i mulighet for ekteskap de selv ikke ønsket, eller de var engstelige for konsekvensene ved ikke lenger à være jomfru. H er virket det som spennet mellom foreldrenes kultur og den norske kulturen skapte problemer som de følte seg alene med. I noen få tilfeller var et avslått ønske om familiegjenforening sentralt for deresfortvilelse. N oen få hadde også opplevd meget traumatiske hendelser i sitt hjemland før de kom til N orge.

0 gså de norske ungdommene hadde opplevd mange vanskelige situasjoner som bidro til deres selvmordsforsøk, og det er ikke riktig å si at innvandrerne hadde større problemer enn de andre. Det var ingen forskjell avhengig av foreldrenes opprinnelsesland når det gjal dt depressive følelser, utagering eller selvtillit, eller andre mål på hvor vondt de unge hadde det.

\section{Kan vi trekke konklusjoner?}

Før vi trekker konklusjoner, er det viktig å understreke svakheter ved disse studiene, og vi vil trekke fram to: For det første er det få unge med innvandrerbakgrunn i studiene, og det er galt å trekke bastante konklusjoner basert på skjebnen til så få personer. Vi risikerer framfor alt å overse forskjeller, som kan gå i begge retninger. Funnene knyttet til de som døde er heller ikke statistisk signifikante, og her kan vi ikke trekke noen konklusjoner, men bare referere tall. For det andre er betegnel sen "unge med innvandrerbak- grunn" svært generell, og omfatter unge med ulik etnisitet, ulik kulturell bakgrunn og ulik religiøs tro. A lle disse og en rekke andre forhold er viktige, se f.eks artikkelen av Vijayakumar i dette nummeret som omhandler religion.

\section{Konklusjon}

M ed disse viktige forbehold er vår konklusjon at vi ikke finner holdepunkter for at unge med innvandrerbakgrunn hadde økt risiko for å foreta selvmordsforsøk.

En slik økt risiko så vi i familier med lav sosial status, først og fremst i familier der foreldrene enten var trygdet eller arbeidsIøse, og i familier som nylig var kommet til N orge. Vi fant ingen forskjell når det gjelder selvmord. Vi fant heller ingen holdepunkter for at unge med innvandrerbakgrunn har større eller mindre problemer enn andre barn. M en de beskriver ofte problemene på en annen måte.

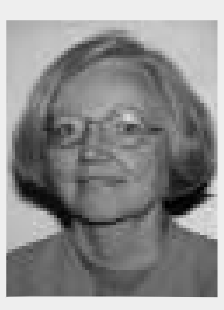

B erit G røholt er barnepsykiater og professorstipendiat ved Senter for barne- og ungdomspsykiatri. H un har lang klinisk erfaring fra arbeid med barn og ungdom. Hennes doktorgradsarbeid omhandlet selvmord og selvmordsforsøk blant barn og unge.

\section{Referanser}

CDC staff. Suicide among children, adolescents and young adults - U nited States, 1980-1992. M orbidity and M ortality W eekly report 1999; 44: 289-291.

G roholt B., Ekeberg 0 ., Wichstrom L., \& H aldorsen T. Youth suicide in N orway, 1990-1992: a comparison between children and adolescents completing suicide and age and gender-matched controls. Suicide and Life-Threatening Behavior 1997; 27: 250-263.

Groholt B., Ekeberg 0 ., W ichstrom L., \& H aldorsen T. Young suicide attempters: a comparison between a clinical and an epidemiological sample. Journal of the $A$ merican $A$ cademy of $C$ hild and $A$ dolescent Psychiatry
Nytt fra Vivat

Ved Kirsti Silvola

U ndervisningsprosjekt Vivat er en del av "Tiltak mot selvmord" - oppfølgingsprosjektet til $\mathrm{H}$ andlingsplan mot selvmord 1994-99. Vivat har ansvaret for kurset "Førstehjelp ved selvmordsfare", utdanner kursledere til dette kurset og støtter kursledernettverket. Kurset er praktisk og tverrfaglig, og er beregnet på enhver som møter selvmordsnære mennesker. Deltakerne lærer å tyde faresignaler og gripe inn ved akutt selvmordsfare.

I begynnelsen av 2002 ble det opprettet regionale koordinatorstillinger (20\% deltidsstillinger) i alle helseregioner. Disse koordinatorene er veiledere som skal støtte kursledere i faglige og praktiske spørsmål. Vi har nå 140 aktive kursledere. C a. 4500 personer har hittil deltatt på kurset "Førstehjelp ved selvmordsfare".

A It kursmateriell foreligger nå på norsk. Høsten 2001 ble boken "Førstehjel p ved selvmordsfare" oversatt og tilpasset norske forhold.

Før sommeren skal V ivat ha etablert egne Internett-sider der det vil bli lagt ut informasjon om kommende kurs, og om hvordan man kan komme i kontakt med kursledere. A dressen er www.unn.no/vivat.

I forbindelse med den Tredje nasjonale konferanse om selvmordsforebygging i Bergen 22. - 23. oktober i år arrangerer Vivat for første gang en nasjonal kursledersamling.

N este kurslederkurs vil etter planen bli holdt i februar 2003 i Sør-N orge. M er informasjon kommer etter hvert på I nternett.

\section{E-post: Vivat@unn.no}

TIf.: 77627819

Faks: 77627530

www.unn.no/vivat 